\title{
Immunolocalization of lactoferrin in surgically resected pigmented skin lesions
}

\author{
G. Tuccari, G. Giuffrè, R. Scarfi, A. Simone, P. Todaro, G. Barresi \\ Department of Human Pathology, University of Messina, Azienda Ospedaliera Universitaria \\ "Policlinico G. Martino", Messina, Italy
}

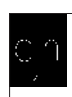

(C)2005, European Journal of Histochemistry

Lactoferrin (Lf) expression was determined immunohistochemically in 57 formalin-fixed paraffin-embedded bioptic samples obtained from an equal number of patients treated by surgery to remove pigmented skin lesions (nevi $=23$; melanoma $=12$; vulgaris and seborrhoeic warts $=12$; basal cell carcinoma $=10$ ); in addition, 10 specimens of normal skin were studied as control. On $3 \mu \mathrm{m}$ thick sections, depigmentation and antigen retrieval procedures were performed. The Lf immunoreactivity was revealed by a rabbit anti-human Lf. Quantification of Lf immunoreactivity was performed using an intensity-distribution (ID) score. Melanocytic cells, regardless of their benign or malignant nature, were consistently stained, with no significant differences in the Lf IDscore between melanomas or nevi. A different intensity of Lf immunoreactivity was encountered in superficial portions of warts, exclusively inside squamous epithelial cells arranged in sheets or whorls of keratin. On the contrary, basal cell carcinomas were always unstained, while a slight Lf positivity was found in focal keratinized areas present in two tumours showing baso-squamous differentiation. The Lf immunoreactivity was localized in the cytoplasm and only occasionally in the nucleus. The biological meaning of Lf in these cases of human skin specimens remains unexplained, although it cannot be ruled out that Lf might be involved in the defense system against tumours, or alternatively, may be used by cells requiring iron availability for their turnover. Moreover, the immunohistochemical expression of Lf in melanocytic lesions might be also related to a Lf-melanin interaction. Finally, the involvement of Lf in skin squamous non-neoplastic elements could be related to its role as one of the molecules modulating an unspecific inflammatory or anti-oxidant response.

Corresponding Author: Prof. Giovanni Tuccari

Department of Human Pathology

Azienda Ospedaliera Universitaria "Policlinico G. Martino"

pad. D Via Consolare Valeria

98125 Messina Italy

Tel. 090 2212539; cell 348-5111548

Fax 090-2938324

E-mail: tuccari@unime.it

Paper accepted on ???? ?, 2005

European Journal of Histochemistry 2005; vol. 49 issue 1 (Jan-Mar):???-???
L actoferrin (Lf), an $80 \mathrm{kDa}$ basic glycoprotein, is a member of the transferrin family of ironbinding proteins which has been originally isolated from human milk (Steijns and Van Hooijdonk, 2000). By radioimmunological and immunoenzymatic procedures, Lf has been detected in many biological fluids as well as in human fetal and adult tissues (Masson et al., 1966; De Vet and Van Gool, 1974; Mason and Taylor, 1978; Brock, 1980; Reitamo et al., 1980; Korsrud and Brandtzaeg, 1982). By immunohistochemistry, the distribution of $L f$ has been investigated in normal human tissues such as stomach, kidney, lung, pancreas, liver and bone marrow (Mason and Taylor, 1978). Lf immunoreactivity has been extensively investigated in human neoplastic conditions with a variable immunohistochemical pattern of this iron-binding protein being reported in adenocarcinomas of the parotid gland (Caselitz et al., 1981), prostatic carcinomas (Barresi and Tuccari, 1984), breast carcinomas (Rossiello et al., 1984; Charpin et al., 1985), thyroid tumours (Tuccari and Barresi, 1985; Barresi and Tuccari, 1987; Cabaret et al., 1992; Asato de Camargo et al., 1996), renal cell carcinomas (Loughlin et al., 1987), gastric adenomas and carcinomas (Tuccari et al., 1989), colorectal adenomas and carcinomas (Tuccari et al., 1992), gallbladder carcinomas (Tuccari et al., 1997), astrocytomas and multiforme glioblastomas (Tuccari et al., 1999).

Under normal conditions, the squamous epithelium of the human skin as well as hair follicles and sebaceous glands do not stain for Lf (Mason and Taylor, 1978). However, in squamous cell carcinomas, a negative staining for Lf has been reported, while one basal cell carcinoma exhibited a few areas of moderate Lf positivity in the vicinity of hair follicles (Mason and Taylor, 1978). In the present study, we have investigated the immunohistochemical distribution pattern of $L f$ in a retrospective series of skin specimens represented by different pigmented 
lesions, since data concerning Lf immunoreactivity in this field of human pathology are lacking.

\section{Materials and Methods}

Lactoferrin (Lf) expression was immunohistochemically investigated in 57 bioptic samples obtained from an equal number of patients (24 men, 33 women, age range 28-74 years), treated by surgery to remove skin pigmented brownish lesions (nevi $=23$; melanomas $=12$; vulgaris and seborrhoeic warts $=12$; basal cell carcinomas $=10$ ); in addition, 10 specimens of normal skin obtained at surgery were studied as control. The skin specimens, fixed in 10\% neutral formalin for 12-24 hours at room temperature, were embedded in paraffin at $55^{\circ} \mathrm{C}$ and cut into $3 \mu \mathrm{m}$ thick sections that successively underwent depigmentation $\left(10 \% \mathrm{H}_{2} \mathrm{O}_{2}\right.$ solution for $48 \mathrm{hrs}$ ) and antigen retrieval procedures (citrate buffer heated in a microwave oven for 3 cycles $\times 5 \mathrm{~min}$ ). For the immunohistochemical study, sections were treated in a moist chamber for 30 min each time with : 1) $0.1 \% \mathrm{H}_{2} \mathrm{O}_{2}$ in methanol to block the intrinsic peroxidase activity; 2) normal sheep serum to prevent unspecific adherence of serum proteins; 3) rabbit anti-human Lf (diluted 1:300; DakoCytomation, Denmark); 4) sheep antirabbit immunoglobulin antiserum (Behring Institute; diluted.1:25); and 5) rabbit anti-horseradish peroxidase-antiperoxidase complexes (DakoCytomation; diluted 1:25). For the demonstration of peroxidase activity, the sections were incubated in darkness (Weir et al., 1974) for 10 min. with 3-3' diaminobenzidine tetra hydrochloride (Sigma Chemical Co., St. Louis, M0, USA), in the amount of $100 \mathrm{mg}$ in $200 \mathrm{~mL} 0.03 \% \mathrm{H}_{2} \mathrm{O}_{2}$ in phosphate-buffered saline (PBS). The nuclear counter staining was performed by Mayer's haemalum.

The specificity of Lf immunostaining was tested on the serial sections of each affected skin specimen by replacing the specific antiserum with either PBS, normal rabbit serum or absorbing with excess purified Lf from human liver and spleen (Sigma Chemical Co.) as well as with pre-absorbed primary antibody: the results were negative. Moreover, the Lf immunoreactivity demonstrated in granules of polymorphonuclear neutrophils present inside skin lesions was used as positive control. Finally, in order to test the inter-run variability of Lf staining, the same Lf-positive parotid sample was used in every run.
Immunostained sections were estimated by light microscopy using $\times 20$ and $\times 40$ objective lenses and x10 eyepiece. Two pathologists using a doubleheaded microscope performed the assessment of immunostained sections on a consensus basis. The percentage of epidermal stained epithelial and melanocytic cells (staining score) was graded as follows: 0 (no staining); 1 ( $>0$ to $5 \%$ ); 2 ( $>5$ to $50 \%)$; and $3(>50 \%)$. Successively, an intensitydistribution (ID) score was calculated by multiplying the staining score by the staining intensity ( weak $=1$; moderate $=2$; strong $=3$ ) similarly to that reported elsewhere (Douglas-Jones et al., 1995; Tuccari et al., 2000).

The possible correlations between the immunohistochemical data, reported as the Lf ID-score, and clinico-pathological data of skin specimens were determined using non-parametric methods (MannWhitney U-test, Kruskal-Wallis $H$-test). A p value less than 0.05 was considered statistically significant.

\section{Results}

The Lf immunoreactivity encountered in normal and pigmented pathological skin specimens is summarized in Table 1.

In all melanocytic lesions, such as nevi or melanomas, an evident immunoreactivity for $L f$ was

Table 1. Immunohistochemical detection of Lf in normal and affected pigmented skin specimens.

\begin{tabular}{lcccccc}
\hline \hline & $\begin{array}{c}\text { Percentage } \\
\text { of positive } \\
\text { specimens }\end{array}$ & \multicolumn{2}{c}{ ID score } & & & \\
\hline & & Median & Min/Max & $\begin{array}{c}\text { Nr. } \\
\text { of cases }\end{array}$ & $\begin{array}{c}\text { Staining } \\
\text { score }\end{array}$ & $\begin{array}{c}\text { Staining } \\
\text { intensity }\end{array}$ \\
\hline Normal skin & $0(0 / 10)$ & 0 & 0 & 0 & & \\
\hline Nevi & $100(23 / 23)$ & 6 & $3 / 9$ & 7 & 3 & +++ \\
& & & & 14 & 3 & ++ \\
& & & & 1 & 3 & + \\
& & & & 1 & 2 & ++ \\
\hline Melanomas & $100(12 / 12)$ & 6 & $3 / 9$ & 3 & 3 & +++ \\
& & & & 6 & 3 & ++ \\
& & & & 3 & 3 & + \\
\hline
\end{tabular}

\begin{tabular}{lcccccc}
$\begin{array}{l}\text { Basal } \\
\text { cell carcinomas* }\end{array}$ & $0(0 / 10)$ & 0 & 0 & 0 & & \\
\hline Warts & \multirow{2}{*}{$100(12 / 12)$} & 6 & $2 / 9$ & 1 & 3 & ${ }^{+++}$ \\
& & & & 7 & 3 & ++ \\
& & & & 1 & 2 & ++ \\
& & & & 3 & 2 & +
\end{tabular}

*A focal Lf immunoreactivity was found in 2 cases with areas of squamous differentiation. 

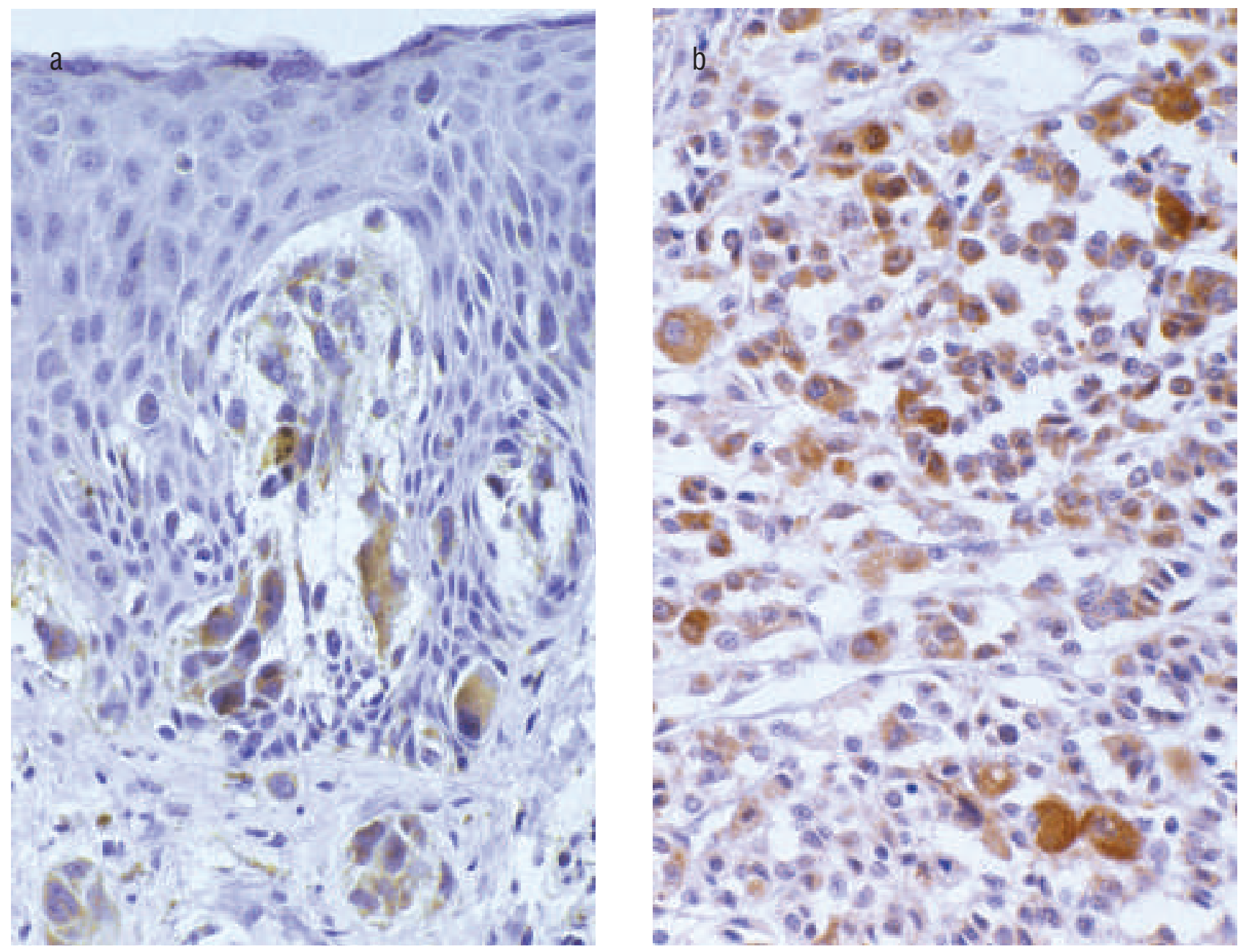

Figure 1. Lf immunoreactivity: (a) an evident cytoplasmic positivity was found in melanocytic elements of compound nevi (arrowhead); (b) an intense staining was appreciable in anaplastic epithelioid cells of melanomas (immunoperoxidase, Mayer's haemalum counterstain).

encountered in neoplastic cells (Figures $l a, b)$. Although the Lf staining was mainly appreciated in the cytoplasm of melanocytes, a clear nuclear Lf immunolocalization (Figure 1 b) was found in a few cases of both lesions. Moreover, no appreciable differences in Lf staining were found among junctional, intradermal or compound nevi, or between spindle and epithelioid cells of melanomas.

In all pigmented warts, a different positivity of Lf staining was encountered (Figure 2). The immunoreactivity was exclusively localized in superficial squamous epithelial cells arranged in sheets or whorls of keratin (Figure 2); no evidence of Lf immunopositivity was noted in lower epidermal portions of warts.

In basal cell carcinomas, neoplastic elements either organized as solid nests or palisading structures were always unstained (Figure 3 ). Nevertheless, in two cases showing a partial squa- mous differentiation, some degree of Lf positivity was present in focal keratinized areas (Figure 3).

No Lf immunoreactivity was noted in epidermal cells of normal control skin specimens, while only a slight occasional Lf immunopositivity was observed in melanocytes present at the dermo-epidermal junction.

When all examined skin specimens were analyzed by non-parametric tests, significant differences $(p<0.0001)$ were found among melanocytic lesions, basal cell carcinomas, warts and normal controls. No significant difference $(p=0.3478)$ was noticed between nevi and melanomas, while an evident significant difference was found between warts and basal cell carcinomas or normal skin control specimens. Moreover, no correlations between Lf immunostaining and age or sex of patients were found. 


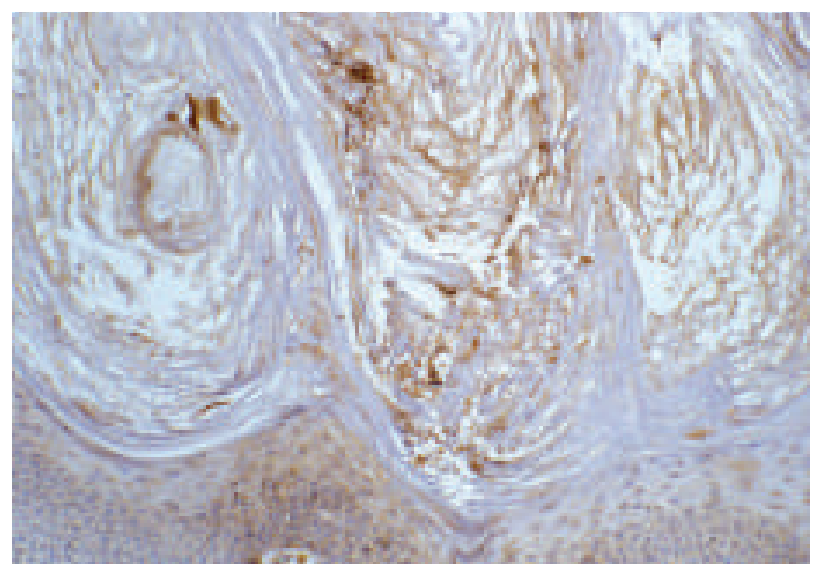

Figure 2. The Lf immunoreactivity was observed in superficial squamous typical cells of warts (immunoperoxidase, Mayer's haemalum counterstain).

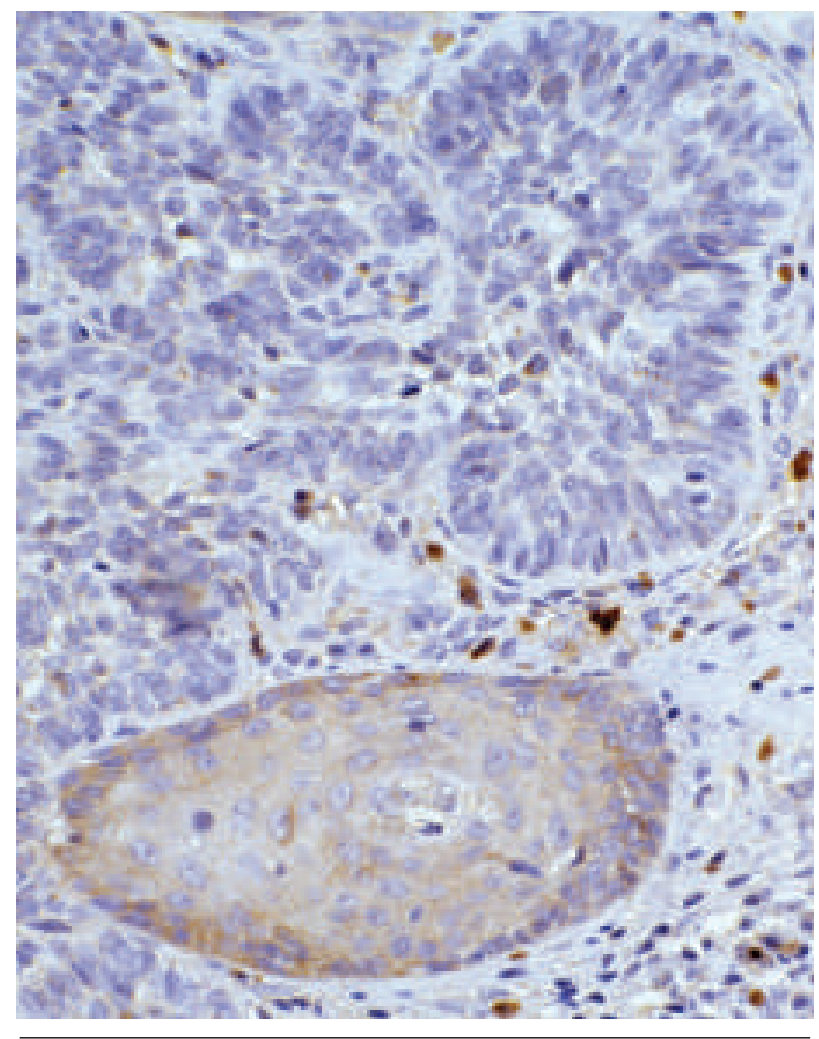

Figure 3. Cells present in basaliomas were always unreactive with Lf. Note the slight Lf immunoreactivity confined to foci of squamous differentiation (arrows). Granulocytes represent the inner control of Lf staining (arrowhead) (immunoperoxidase, Mayer's haemalum counterstain).

\section{Discussion}

The present study represents the first report concerning Lf immunostaining in human pigmented skin lesions such as nevi, melanomas, warts and basal cell carcinomas. Lf was detected in all examined pathological samples with the exception of basal cell carcinomas. Melanocytic cells, regardless of their benign or malignant nature, were constantly stained, with no significant differences in the Lf ID-score between melanomas or nevi. A different positivity of Lf immunoreactivity was encountered in superficial portions of warts, exclusively inside squamous epithelial cells arranged in sheets or in whorls of keratin. On the contrary, basal cell carcinomas were always unstained, while a slight Lf positivity was found in focal keratinized areas present only in two tumours showing a baso-squamous differentiation.

The Lf immunoreactivity was always localized in the cytoplasm and only occasionally in the nucleus. In our opinion, the site of Lf immunoreactivity in both the nucleus and cytoplasm is not surprising since this secretory protein has been immunohistochemically detected in the nucleus, mainly in nucleoli, and has been thought to be involved in ribosomal biogenesis (Garrè et al., 1992; Penco et al., 2001). On the other hand, after its transport into the nucleus, Lf is able to bind to specific DNA sequences, thus activating transcription (Penco et al., 2001).

Many biological functions of $L f$ have been addressed, including regulation of iron homeostasis, antioxidant and immunoregulatory activities, bacteriostatic and bactericidal effects, and the ability to curb the proliferation of other microbes such as fungi and viruses (Brock 1995; Defer et al., 1995; Fujihara and Hayashi, 1995; Levay and Viljoen, 1995; Lonnerdal and Lyer, 1995; Ikeda et al., 1998; Tanaka et al., 1999; Tuccari et al., 2002). The biological meaning of Lf in our cases of human skin specimens still remains unexplained. However, the possibility that Lf might be involved in the defence system against tumours cannot be excluded: Lf immunoexpression as the result of an endogenous synthesis by melanocytic cells would increase the availability of this anti-oxidant component. In this way, it has been suggested that Lf inhibits cell proliferation and suppresses tumour growth in vivo (Damiens et al., 1998; Damiens et al., 1999; Norrby et al., 2001), although the molecular mechanisms underlying these effects remain unknown. Nevertheless, it has been reported that treatment of breast carcinoma MDA-MB-231 cells with human $L f$ induces growth arrest at the $G 1$ to $S$ transition stage of the cell cycle (Damiens et al., 1999). In addition, it has been shown in adult rats that $L f$ treatment significantly inhibited the 
VEGF(165)-mediated response in terms of microvessel spatial extension, overall vascularity and incidence of crossover (Norrby et al., 2001). Finally, these effects of Lf on target cells appear to depend on the cell phenotype. In fact, Lf does not modify the susceptibility to lysis of haematopoietic cells such as Jurkat and K-562 cells, but does significantly increase that of the breast and colon epithelial cells (Damiens et al., 1998).

On the other hand, it is well known that Lf has a high affinity for iron, which has been considered an essential nutrient for rapidly dividing cells, such as tumour cells, exploiting various metabolic cellular processes such as oxidative phosphorylation and RNA and DNA synthesis (Weinberg, 1984; Shoji and Ozawa, 1986). Therefore, neoplastic melanocytes, requiring iron availability for their turnover would need Lf, similarly to that suggested elsewhere for other neoplasms (Tuccari and Barresi, 1985; Tuccari et al., 1997; Tuccari et al., 1999). In addition, the presence of iron in nuclei of melanoma cells has been documented (Bedrick et al., 1991) and melanin formation could be induced by $\mathrm{Fe}^{2+}$ and $\mathrm{Fe}^{3+}$ (Mani et al., 2001).

An Lf-melanin interaction in melanocytes has been reported in vitro, suggesting that Lf promotes the process of melanin polymerization at an acidic $\mathrm{pH}$ (Sharma et al., 2001). Whether the immunohistochemical expression of Lf in melanocytic lesions is related to the involvement of this ironbinding protein in the melanin formation process or affects some essential function of melanin within the cell remains to be further investigated.

The presence of Lf in neoplastic melanocytic elements might be related to the production of this iron-binding protein in the tumour itself as suggested by Lf immunostaining, although this interpretation should be checked by methods other than morphological analysis. Alternatively, the cytoplasmic immunolocalization of Lf in neoplastic pigmented cells cannot reflect an intracellular synthesis since it is the consequence of defective or functionally impaired $L f$ receptors. In fact, specific Lf-binding sites have been shown in a human neoplastic cell line (Roiron et al., 1989); receptor-mediated endocytosis was hypothesized, similarly to that demonstrated for transferrin in growing cells (Iacopetta et al., 1983). In this way, the intracellular presence of Lf immunoreactivity may reveal the degree of transmembrane iron transfer.

Another intriguing finding in this study is the demonstration of Lf in areas with squamous differentiation of pigmented skin lesions, either in warts or, in two cases, of baso-squamous tumours. In particular, the immunohistochemical appearance of Lf in sheets and whorls of keratin seems to be related to the degree of cell maturation towards squamous lineage in neoplastic and non-neoplastic skin lesions with evidence of keratinisation. It has been reported that squamous parts of other neoplasms, such as parotid carcinomas and salivary squamous cell carcinomas, were always unreactive to Lf, its presence being restrained to the glandular parts of the tumour. This suggests that Lf could be a marker of glandular or acinar differentiation (Caselitz et al., 1981). Nevertheless, the involvement of Lf in skin squamous elements may be due to its role as one of the molecules modulating an unspecific inflammatory or anti-oxidant response, similarly to that reported elsewhere (Baynes and Berzwoda, 1994; Baveye et al., 1999). Therefore, it could be argued that, in comparison to normal epidermal cells, the appearance of Lf in squamous non-neoplastic cells may be a result of its endogenous synthesis which could activate the host defence system by Lf-specific functions, such as antibody synthesis, interleukin activation and T-lymphocyte proliferation.

\section{References}

Asato de Camargo RY, Longatto Filho A, Ferreira Alves VA, Bisi H, Takami Kanamura C, Alves Abelin NM. Lactoferrin in thyroid lesions. Immunoreactivity in fine needle aspiration biopsy samples. Acta Cytol 1996; 40: 408-13.

Barresi G, Tuccari G. Lactoferrin in benign hypertrophy and carcinomas of the prostatic gland. Virchows Arch (A) 1984; 403: 59-66.

Barresi G, Tuccari G. Iron-binding proteins in thyroid tumours. An immunocytochemical study. Path. Res. Pract. 1987; 182: 344-51.

Baveye S, Elass E, Mazurier J, Spik J, Legrand D. Lactoferrin: a multifunctional glycoprotein involved in the modulation of the inflammatory process. Clin Chem Lab Med 1999; 37: 281-6.

Baynes RD, Bezwoda WR. Lactoferrin and the inflammatory response. Adv Exp Med Biol 1994; 357: 133-41.

Bedrick AE, Ramasamy G, Tchertkoff V. Histochemical determinations of copper, zinc, and iron in pigmented nevi and melanoma. Am J Dermatopathol 1991; 13:575-8.

Brock J. Lactoferrin in human milk: its role in iron absorption and protection against enteric infection in the newborn infant. Arch Dis Child 1980; 55: 417-21.

Brock J. Lactoferrin: a multifunctional immunoregolatory protein? Immunol Today 1995; 16: 417-9.

Cabaret V, Vilain M0, Delobelle-Deroide A, Vanseymortier L. Détection immunohistochimique de la céruloplasmine et de la lactoferrine sur une sèrie de 59 tumeurs thyroidiennes. Ann Pathol 1992; 12: 34752.

Caselitz J, Jaup T, Seifert G. Lactoferrin and lysozyme in carcinomas of the parotid gland. Virchows Arch (A) 1981; 394: 61-73.

Charpin C, Lachard A, Pourreau-Schneider N, Jacquemier J, Lavaut

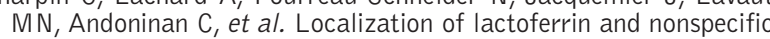
cross-reacting antigen in human breast carcinomas. Cancer 1985; 55: 2612-7.

Damiens E, Mazurier J, el Yazidi I, Masson M, Duthille I, Spik G, et al. 


\section{G. Tuccari et al.}

Effects of human lactoferrin on NK cell cytottoxicity against haematopoietic and epithelial tumour cells. Biochim Biophys Acta 1998; 1402: 277-87.

Damiens E, El Yazidi I, Mazurier J, Duthille I, Spik G, Boilly-Marer Y. Lactoferrin inhibits $\mathrm{G} I$ cyclin-dependent kinases during growth arrest of human breast carcinoma cells. J Cell Biochem 1999; 74: 486-98.

Defer MC, Dugas B, Picard 0, Damais C. Impairment of circulating lactoferrin in HIV-1 infection. Cell Mol Biol 1995; 41: 417-21.

De Vet BJCM, Van Gool J. Lactoferrin and iron absorption in the small intestine. Acta Med Scand 1974; 196: 393-402.

Douglas-Jones AG, Schmid KW, Bier B, Horgan K, Lyons K, Dallimore $N D$, et al. Metallothionein expression in duct carcinoma in situ of the breast. Hum Pathol 1995; 26: 217-22.

Fujihara T, Hayashi K. Lactoferrin inhibits herpes simplex virus type-1 (HSV-1) infection to mouse cornea. Arch Virol 1995; 140: 1469-72.

Garrè C, Bianchi-Scarra G, Sirito M, Musso M, Ravazzolo R. Lactoferrin binding sites and nuclear localization in $\mathrm{K} 562(\mathrm{~S})$ cells. J Cell Physiol 1992; 153: 477-82.

Iacopetta BJ, Morgan EH, Yeoh GCT. Receptor-mediated endocytosis of transferrin by developing erythroid cells from the fetal rat liver. $J$ Histochem Cytochem 1983; 31:336-44.

Ikeda M, Sugiyama K, Tanaka T, Tanaka K, Sekihara H, Shimotohno K, et al. Lactoferrin markedly inhibits hepatitis $\mathrm{C}$ virus infection in cultured human hepatocytes. Biochem Biophys Res Commun 1998; 245: 549-53.

Korsrud FR, Brandtzaeg P. Characterization of epithelial elements in human major salivary glands by functional markers: localization of amylase, lactoferrin, lysozyme, secretory component, and secretory immunoglobulins by paired immunofluorescence staining. J Histochem Cytochem 1982; 30: 657-66.

Levay PF, Viljoen M. Lactoferrin: a general review. Haematologica 1995; 80: 252-67.

Lonnerdal B, Lyer S. Lactoferrin: molecular structure and biological function. Annu Rev Nutr 1995; 15: 93-110.

Loughlin $K R$, Gittes RF, Partridge $D$. The relationship of lactoferrin to the anemia of renal carcinoma. Cancer 1987; 59: 566-71.

Mani I, Sharma V, Tamboli I, Raman G. Interaction of melanin with proteins - The importance of an acidic intramelanosomal $\mathrm{pH}$. Pigment Cell Res 2001; 14: 170-9.

Mason DY, Taylor CR. Distribution of transferrin, ferritin and lactoferrin human tissues. J Clin Pathol 1978; 31: 316-27.

Masson $\mathrm{PL}$, Heremans JF, Dire $\mathrm{CH}$. An iron-binding protein common to many external secretions. Clin Chim Acta 1966; 14: 735-9.

Norrby K, Mattsby-Baltzer I, Innocenti M, Tuneberg S. Orally administered bovine lactoferrin systematically inhibits VEGF(165)-mediated angiogenesis in the rat. Int $J$ Cancer 2001; 91: 236-40.

Penco S, Scarfi S, Giovine M, Damonte G, Millo E, Villaggio B, et al. Identification of an import signal for, and the nuclear localization of, human lactoferrin. Biotechnol Appl Biochem 2001; 34: 151-9.

Reitamo S, Kontinnen YT, Segerber-Kontinnen M. Distribution of lactoferrin in human salivary glands. Histochemistry 1980; 66: 285-91.

Roiron D, Amouric M, Marvaldi J, Figarella C. Lactoferrin-binding sites at the surface of HT29-D4 cells. Eur J Biochem 1989; 186: 367-73.

Rossiello R, Carriero MV, Giordano GG. Distribution of ferritin, transferrin and lactoferrin in breast carcinoma tissue. J Clin Pathol 1984; 37: 51-5.

Sharma AK, Kumar S, Sharma V, Nagpal A, Singh N, Tamboli I, et al. Lactoferrin-melanin interaction and its possible implications in melanin polymerization: crystal structure of the complex formed between mare lactoferrin and melanin monomers at 2.7-? resolution. Proteins 2001; 45: 229-36.

Shoji A, Ozawa E. Necessity of transferrin for RNA synthesis in chick myotubes. J Cell Physiol 1986; 127: 349-56.

Steijns JM, Van Hooijdonk ACM. Occurrence, structure, biochemical properties and technological characteristics of lactoferrin. Brit $\mathrm{J}$ Nutr 2000; 84:11-7.

Tanaka K, Ikeda M, Nozaki A, Kato N, Tsuda H, Saito S, et al. Lactoferrin inhibits hepatitis $C$ virus viremia in patients with chronic hepatitis C: a pilot study. Jpn J Cancer Res 1999; 90: 367-71.

Tuccari G, Barresi G. Immunohistochemical demonstration of lactoferrin in follicular adenomas and thyroid carcinomas. Virchows Arch (A) $1985 ; 406: 67-74$.
Tuccari G, Barresi G, Arena F, Inferrera C. Immunocytochemical detection of lactoferrin in human gastric carcinomas and adenomas. Arch Pathol Lab Med 1989; 113: 912-6.

Tuccari G, Rizzo A, Crisafulli C, Barresi G. Iron-binding proteins in human colorectal adenomas and carcinomas: an immunocytochemical investigation. Histol Histopathol 1992; 7: 543-7.

Tuccari G, Rossiello R, Barresi G. Iron binding proteins in gallbladder carcinomas. An immunocytochemical investigation. Histol Histopathol 1997; 12; 671-6.

Tuccari G, Giuffrè G, Crisafulli C, Barresi G. Immunohistochemical detection of lactoferrin in human astrocytomas and multiforme glioblastomas. Eur J Histochem 1999; 43: 317-22.

Tuccari G, Giuffrè G, Arena F, Barresi G. Immunohistochemical detection of metallothionein in carcinomatous and normal human gastric mucosa. Histol Histopathol 2000; 15: 1035-41.

Tuccari G, Villari D, Giuffrè G, Simone A, Squadrito G, Raimondo G, et al. Immunohistochemical evidence of lactoferrin in hepatic biopsies of patients with viral or cryptogenetic chronic liver disease. Histol Histopathol 2002; 17: 1077-83.

Weinberg ED. Iron withholding: a defense against infection and neoplasia. Physiol Rev 1984; 64: 65-102.

Weir EE, Pretlow TG, Pitts A. A more sensitive and specific histochemical peroxidase stain for the localization of cellular antigen by the enzyme-antibody conjugate method. J Histochem Cytochem 1974; 22: 1135-40. 